\title{
HEIGHT OF THREE HARDWOOD SPECIES GROWING ON MINE SITES RECLAIMED USING THE FORESTRY RECLAMATION APPROACH COMPARED TO NATURAL CONDITIONS ${ }^{1}$
}

\begin{abstract}
Kara Dallaire, Jeff Skousen, and Jamie Schuler ${ }^{2}$
Abstract: Coal is an important source of energy for electricity and is used in making steel and various other products. West Virginia is the largest coal producing state within the Appalachian region. Surface mining of coal drastically disturbs ecologically diverse forests and the reforestation of these areas after mining is an important first step to helping restore their ecosystem functions. After mining, operators are often left with brown and gray sandstone to use as topsoil substitutes. Brown sandstone has been more weathered and has physical and chemical properties that are better for tree growth (lower $\mathrm{pH}$, higher percent fines, and higher available nutrients) than gray sandstone. Two study sites were established on former mine sites in West Virginia to assess the effects of brown and gray sandstone, with and without mulch treatments, on tree establishment. Tree growth data for tulip poplar (Liriodendron tulipifera L.), white oak (Quercus alba L.) and northern red oak (Q. rubra L.), and for soil samples (analyzed for $\mathrm{pH}, \mathrm{EC}$, percent fines, and extractable nutrients) have been collected annually for the last 10 years. The $\mathrm{pH}$ of brown sandstone was 5.2 to 5.4, gray sandstone was 6.5 to 6.8 , and mulch treatments were 7.0. Percent fines ranged from 42 to $60 \%$ on all treatments. The mulch treatment had high levels of $\mathrm{Ca}\left(197 \mathrm{cmol}_{\mathrm{c}} / \mathrm{kg}\right)$. The height growth of each tree species on both mine sites was compared to the growth of trees growing on clear-cut areas at the Fernow Forest, WV. In addition, an estimated site index prior to disturbance was calculated and used to predict tree growth rates based on NRCS soil survey data. Tree heights $(25$ to $175 \mathrm{~cm}$ ) on gray sandstone were significantly lower than height on brown sandstone (197 to $544 \mathrm{~cm}$ ) for all three species. Trees on mulched plots were up to $229 \mathrm{~cm}$ taller than trees on un-mulched plots. Tulip poplar height on the brown treatment $(544 \mathrm{~cm})$ was greater than on a clear-cut area with a site index 62 at 10 years $(503 \mathrm{~cm})$. Tree heights on average were $50 \%$ lower on mined sites compared to heights calculated from pre-mining site indices.
\end{abstract}

${ }^{1}$ Paper presented at the 2015 National Meeting of the American Society of Mining and Reclamation, Lexington, KY Reclamation Opportunities for a Sustainable Future June 6 - 11, 2015. R.I. Barnhisel (Ed.). Published by ASMR; 1305 Weathervane Dr., Champaign, IL 61821.

${ }^{2}$ Kara Dallaire (Graduate Student) and Jeff Skousen (Professor), Division of Plant and Soil Science; and Jamie Schuler (Professor), Division of Forestry and Natural Resources, West Virginia University, Morgantown, WV, 26505

Journal American Society of Mining and Reclamation, 2015 Volume 4, Issue 2 pp20-35 DOI: http://doi.org/10.21000/JASMR15020020 


\section{Introduction}

Coal is an important source of energy and is used to make steel and various other products (Bise, 2013). There are more than 100 minable coal seams within the Appalachian region, and West Virginia is the largest coal-producing state within this region (Bise, 2013; U.S. EIA, 2013). In 2012, West Virginia had 104 active surface mines that produced over 36 million $\mathrm{Mg}$ of coal (U.S. EIA, 2013). Approximately $78 \%$ of West Virginia is covered in valuable eastern deciduous forests and surface mining drastically disturbs these ecologically diverse forests. Reforestation of mined lands is important because forests provide important benefits to society including wood and fiber production, watershed and hydrologic values, wildlife habitat, carbon sequestration, and ecosystem stability (Burger, 1999).

The first surface mining legislation in West Virginia was enacted in 1939 (Bowling, 1978; Plass, 2000). Revegetation of all surface mine spoils was required and specific reclamation laws were established. Many hectares of mined land were successfully reclaimed to forest plantations; however, enforcement of these laws was difficult and large areas remained un-reclaimed. As developments in mining equipment were made, the area disturbed for surface mining increased. Public concern of the effects of mining on human safety and the environment increased as the total area disturbed by mining grew (Plass, 2000). The Surface Mining Control and Reclamation Act (SMCRA) was enacted in 1977 by the federal government to address safety and environmental issues and caused a major change in reclamation practices (Burger, 1999; Skousen and Zipper, 2013 and 2014). Under SMCRA, selected overburden materials are allowed to be substituted for topsoil when the substituted material is at least as equally sustaining to vegetation as the topsoil. Mass stability of slopes was required under SMCRA which encouraged excessive grading and smoothing of reclaimed land (Skousen and Zipper, 2014). The establishment of a grass and legume cover was required on all disturbances. Fertilizer and liming treatments became accepted mine land reclamation treatments because they improved the growth of the ground cover crops. Reforestation had been previously an important reclamation strategy for mined lands, but the new reclamation requirements shifted the emphasis for revegetation from trees to herbaceous covers. With this emphasis of ground cover for erosion control, these herbaceous cover crops caused severe competition with tree seedlings on compacted soils, resulting in low tree survival, and tree planting decreased. As a result, fewer mined areas were returned to forested lands (Plass, 2000), 
fewer trees naturally re-colonized reclaimed mined sites, and the loss of Appalachian forests has been ongoing since the enactment of SMCRA (Zipper et al., 2011).

The Appalachian Regional Reforestation Initiative (ARRI) was created to encourage restoration of high quality forests on reclaimed mines in the Eastern USA (Angel et al., 2005). ARRI developed the Forestry Reclamation Approach (FRA) to encourage reclaiming coal mines to forests under SMCRA (Burger et al., 2005). The following five steps are recommended:

1. Create a suitable rooting medium for good tree growth that is no less than $1.2 \mathrm{~m}$ deep and comprised of topsoil, weathered sandstone and/or the best materials.

2. Loosely grade the topsoil or topsoil substitute established in step one to create a noncompacted growth medium.

3. Use ground covers that are compatible with growing trees.

4. Plant early successional trees for wildlife and soil stability and commercially valuable trees.

5. Use proper tree planting techniques.

Due to the steep terrain, it is often not possible to collect and save the topsoil in West Virginia and other Appalachian regions. Weathered, brown sandstones and unweathered, gray sandstones that are exposed during mining are commonly used as substitute topsoil materials. Brown sandstone is found closer to the surface and typically has a $\mathrm{pH}$ ranging from 4.0 to 5.5 due to oxidizing conditions (Haering et al., 2004). In addition, brown sandstones have low electrical conductivity (EC), moderately acidic $\mathrm{pH}$, and high percentages of fines $(<2 \mathrm{~mm})$, all correlated with increased tree growth (Daniels and Amos, 1985; Rodrigue and Burger, 2004). Gray sandstone is found underneath brown sandstone and is not oxidized by weathering processes. The $\mathrm{pH}$ of gray sandstone ranges from 7.5 to 8.0 (Haering et al., 2004; Emerson et al., 2009). The weathered, brown sandstone is the preferred topsoil substitute in restoration of forest trees (Skousen et al., 2011). Numerous studies have shown that brown sandstone has superior tree growth over gray sandstone (Angel et al., 2008; Emerson et al., 2009; Sena et al., 2014; Showalter et al., 2010; Wilson-Kokes, et al., 20013a and 2013b).

Tree growth can be improved with amendments on reclaimed sites (Angel et al., 2006; Thomas and Skousen, 2011; Wilson-Kokes et al., 2013a). In a study by Angel et al. (2006), the addition of bark mulch improved the growth of two species on un-compacted plots on a reclaimed coal 
mine in eastern Kentucky. Wilson-Kokes et al. (2013b) found that adding bark mulch to both brown and gray sandstone increased the growth of hardwood species on a reclaimed coal mine in West Virginia. Another study in West Virginia, by Thomas and Skousen (2011), also found that tree growth was improved on both gray and brown sandstone when bark mulch was added.

Site index (SI) is usually defined as the total height of dominant and co-dominant trees at 50 years total age and can be used to estimate the site quality of a stand for a particular species. Site quality is an estimate of the relative productivity of forestlands and calculated from height measurements since the height growth of dominant and co-dominant trees is related to site quality in a fully stocked stand (Carmean et al., 1989). The rate of height growth is related to site quality (Carmean, 1975). When calculating SI for a stand, free growing, uninjured, dominant, and codominant trees from a well-stocked, even-aged stand are used. SI curves are specific to species, geographic region, and the soil and/or topography (Carmean et al., 1975). SI is related to surface soil depth, subsoil texture, aspect, slope position, and steepness (Carmean, 1977). Higher SI was found on sites with favorable site conditions for growing trees. Mine soils may have lower SI due to their lower soil quality, particularly when gray sandstone is used.

The purpose of this paper was to compare the height growth of tulip poplar (Liriodendron tulipifera L.), white oak (Quercus alba L.), and northern red oak (Q. rubra L.) from two different mine sites, with different soil treatments, in West Virginia to the growth of the same species growing under undisturbed conditions. The undisturbed heights come from a forest that was clearcut. In addition, pre-mine site index for each mine site was estimated using information from the NRCS Web Soil Survey to estimate heights of trees prior to mining.

\section{Materials and Methods}

\section{Study Sites and Treatment:}

Tree height data from two mine sites in West Virginia and a study site from the Fernow Experimental Forest was evaluated for this paper. In addition, estimated pre-mine site indices for each of the mine sites were calculated from the NRCS Web Soil Survey. One mine site has two different soil treatments and the other has three different soil treatments. Table 1 lists all the study sites and treatments used and they are each described further on the next page. 
Table 1. Abbreviations used to describe all the treatments and studies used to compare tree growth on two reclaimed coal mines to tree growth in natural areas.

\begin{tabular}{lc}
\hline Treatment & Abbreviation \\
\hline Birch River - brown sandstone $^{1}$ & BR-B \\
Birch River - gray sandstone & BR-G \\
Birch River - mulch & BR-M \\
Catenary - brown sandstone & C-B \\
Catenary - gray sandstone & C-G \\
Clear-cut with release - SI 62 & CR-62 \\
Clear-cut with release - SI 75 & CR-75 \\
Pre-mining - Birch River & PBR \\
Pre-mining - Catenary & PC \\
${ }^{1}$ Combined 1.2 and 1.5 m plots. &
\end{tabular}

The first mine site is the Birch River mine, located in Webster County, and owned by Arch Coal (38²5'31.74'N, 80³6’39.74'W) and was established in 2006. A 2.5-ha experimental plot was established to determine the effects of soil amendments on tree growth and survival on brown and gray sandstone. Half the plot was constructed with approximately $1.5 \mathrm{~m}$ of brown sandstone and the other half was constructed with approximately $1.5 \mathrm{~m}$ of gray sandstone. Plots were left un-compacted. Bark mulch was applied to the center of the plot over parts of both brown and gray sandstone plots. Eleven 2.7-m-wide transects that spanned the width of the plot were established. Yearly measurements of height and diameter at $2.5 \mathrm{~cm}$ have been made on all trees within these transects, except in 2013. Gray sandstone, brown sandstone, and the mulch treatment are the three treatments used from this site.

The second mine site is the Catenary mine, located in Kanawha, Raleigh, and Boone counties (38 $\left.5^{\circ} 28^{\prime} \mathrm{N}, 81^{\circ} 26^{\prime} 37^{\prime \prime} \mathrm{W}\right)$ and was established in 2005. The Catenary Mine is owned by Patriot Coal and operated by Catenary Coal Company. Three plots were established with two plots being constructed of weathered brown sandstone on the surface, one with $1.5 \mathrm{~m}$ depth and the other with $1.2 \mathrm{~m}$ depth. The third plot was constructed by placing $1.5 \mathrm{~m}$ of un-weathered gray sandstone on the surface. One half of each plot was considered "un-compacted" and received only one or two passes of the bulldozer, while the other half received several passes of the bulldozer and was considered "compacted." Two 2.7-m-wide by 195-m-long transects were established in an "X" 
pattern across each of the six treatments. Yearly measurements of height and diameter at $2.5 \mathrm{~cm}$ have been made on all trees within these transects, except for 2010 and 2013.

A total of twelve tree species were planted at each site on $2.4 \mathrm{~m}$ centers. For the purposes of this paper, only tulip poplar (Liriodendron tulipifera L.), white oak (Quercus alba L.) and northern red oak (Q. rubra L.) are discussed.

Tree growth data from the Birch River and Catenary sites were compared to data from a study from the Fernow Experimental Forest near Parsons, West Virginia (Smith, 1983; Trimble, 1973). The Fernow Forest has elevations ranging from 533 to $1113 \mathrm{~m}$, annual precipitation of $147 \mathrm{~cm}$, shallow soils derived from sandstone, shale, or limestone, and commercially important tree species (USDA, 2014a). The Fernow Experimental Forest was selected because site conditions are similar to those of the mine sites. The study by Smith (1983) measured heights of tulip poplar and northern red oak growing on two sites that had been clear-cut, one with a SI of 75 and the other with SI 62. The trees in this study were released from all competition each year. This study was chosen to show the rates of trees growing under ideal conditions (free from competition) for average and low site qualities.

In addition, the NRCS 2015 Web Soil Survey was accessed to estimate the forest productivity (SI) at each site prior to disturbance for each of the three species. The pre-mining SI for each mine site was determined by calculating a weighted average of SI listed for the site in the soil survey (Web Soil Survey). Once an average SI was calculated at each site for northern red oak, white oak, and tulip poplar, this number was used to estimate the height of trees each year up to the age of 12. In order to calculate the estimated heights for the younger trees, the formulation equation from Carmean et al. (1989) was used. The formulation equation is:

$$
H=b_{1} S^{b_{2}\left(1-e^{b_{3} A}\right)^{\wedge} b_{4} S^{b_{5}}}
$$

$\mathrm{H}=$ Height; bi = Regression Parameters; $\mathrm{S}=$ Site Index; and A = Age

The pre-mining SI at Birch River was 78 for both northern red oak and white oak, and 92 for tulip poplar (USDA, 2014b) (Table 2). At the Catenary mine, the SI for northern red oak was 78, while white oak and tulip poplar had higher SI at 85 and 95, respectively (USDA, 2014b) (Table 2). 
Table 2. Pre-mining site indexes (SI) for northern red oak, white oak, and tulip poplar at the Birch River and Catenary mines in West Virginia.

\begin{tabular}{lccc}
\hline Site & Northern red oak SI & White oak SI & Tulip poplar SI \\
\hline Birch River & 78 & 78 & 92 \\
Catenary & 78 & 85 & 95 \\
\hline
\end{tabular}

\section{$\underline{\text { Results and Discussion }}$}

Table 3 shows the $\mathrm{pH}, \mathrm{EC}$, and percent fines of the Birch River and Catenary mines from samples collected in 2014. The $\mathrm{pH}$ of the brown sandstone (BR-B and C-B) from both mine sites was within the typical range of weathered sandstone 4.5 to 5.5 (Emerson et al., 2009; Haering et al., 2004; Wilson-Kokes et al., 2013a and 2013b). Typically, unweathered sandstone from the Appalachian region has a higher pH (7.5 to 8.0) (Emerson et al., 2009; Haering et al., 2004; Wilson-Kokes et al., 2013a and 2013b) and the pH from both gray sandstone sites (BR-G and CG) was lower. The average $\mathrm{pH}$ of the mulch treatment (BR-M) was the highest (7.0). Limestone gravel was added to the mulch as an aggregate at the saw mill and is likely the cause of the high $\mathrm{pH}$. The $\mathrm{pH}$ of the pre-mining soils (PBR and PC) and the clear-cut soils (CC-62 and CC-75) was slightly more acidic than any of the mine soils (4.1-5.2) (NCSS, 2015). EC was very low, with the highest values being $0.04 \mathrm{dS} / \mathrm{m}$ on the mulch treatment (BR-M). Percent fines ranged from 42 to $60 \%$, with no apparent difference between any treatments or sites.

Table 3. Soil properties (pH, EC, percent fines) of the Birch River and Catenary mine sites in 2014.

\begin{tabular}{lccc}
\hline & & \multicolumn{3}{c}{ Properties } \\
\cline { 2 - 4 } Treatment & $\mathrm{pH}$ & EC $(\mathrm{dS} / \mathrm{m})$ & Fines $(\%)$ \\
\hline BR-B & 5.2 & 0.01 & 45 \\
BR-G & 6.5 & 0.01 & 49 \\
BR-M & 7.0 & 0.04 & 43 \\
C-B & 5.4 & 0.01 & 60 \\
C-G & 6.8 & 0.01 & 42 \\
CC-62, CC-75 & $4.1-5.2$ & 0.0 & Unknown \\
PB & $4.6-4.7$ & 0.0 & Unknown \\
PC & $4.7-4.9$ & 0.0 & Unknown \\
\hline
\end{tabular}

Extractable nutrient information is reported in Table 4. Calcium, $\mathrm{Mg}$, and $\mathrm{P}$ concentrations between gray and brown sandstone and between mine sites were similar. For the mulch treatment (BR-M), Ca concentration was much higher and $\mathrm{Mg}$ and $\mathrm{K}$ concentrations were slightly higher. Aluminum concentrations for gray sandstone and the mulch treatments were similar, while the concentration in the brown treatments was higher. Iron concentration was lowest in the mulch 
treatment $(51 \mathrm{mg} / \mathrm{kg}$ in BR-M) and ranged from 126 to $219 \mathrm{mg} / \mathrm{kg}$ in the gray (BR-G and C-G) and brown (BR-G and C-G) treatments. The P concentration in Catenary gray sandstone (C-G) was much higher $(180 \mathrm{mg} / \mathrm{kg}$ ) than the other treatments (23 to $46 \mathrm{mg} / \mathrm{kg}$ ). Mehlich 1 extractable nutrient information was not available for the clear-cut sites (CC-62 and CC-75) or the predisturbance soils (PBR and PC).

Table 4. Extractable nutrients ( $\mathrm{Ca}, \mathrm{Mg}, \mathrm{K}, \mathrm{Al}, \mathrm{Fe}, \mathrm{P})$ from mine soil samples collected from the Birch River and Catenary mines in 2014.

\begin{tabular}{|c|c|c|c|c|c|c|}
\hline \multirow[b]{2}{*}{ Treatment } & \multicolumn{6}{|c|}{ Element } \\
\hline & $\mathrm{Ca}$ & $\mathrm{K}$ & $\mathrm{Mg}$ & $\mathrm{Al}$ & $\mathrm{Fe}$ & $\mathrm{P}$ \\
\hline & -------- & $\operatorname{nol}_{\mathrm{c}} /$ & $-\cdots$ & 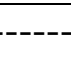 & $-\mathrm{mg} /$ & ----- \\
\hline BR-B & 6 & 0.6 & 4 & 402 & 219 & 38 \\
\hline BR-G & 6 & 0.3 & 4 & 113 & 126 & 46 \\
\hline BR-M & 197 & 12 & 12 & 115 & 51 & 23 \\
\hline S-B & 7 & 0.6 & 5 & 431 & 154 & 41 \\
\hline S-G & 10 & 0.4 & 5 & 150 & 149 & 180 \\
\hline
\end{tabular}

The higher levels of $\mathrm{Al}$ found in the brown sandstone was likely due to the fact that brown sandstone had been exposed to more weathering than gray sandstone (Wilson-Kokes, 2013b). While the $\mathrm{P}$ concentration in the Catenary gray treatment was high $(180 \mathrm{mg} / \mathrm{kg})$, it was still within the range of other reported $\mathrm{P}$ levels in gray sandstone (Wilson-Kokes, 2013b). The high $\mathrm{Ca}$ concentration in the mulch treatment was also expected due to the incorporated limestone. Calcium has been shown to increase the growth of hardwood trees in poor soils (Bigelow and Canham, 2007).

Figure 1 compares the heights of northern red oak growing on the two mine sites, the two clearcut sites (SI of 62 and 72), and the heights calculated from the pre-mining SI. From the graph, it is clear that tree growth is slow on gray sandstone at both mine sites, with both showing almost no growth at all. The Catenary reforestation study was established 2 years prior to the study at Birch River, so the lines for Catenary extend to 10 years, while Birch River only extend to 8 years. The trees on brown sandstone (BR-B and C-B) are growing much faster than those on gray sandstone at both sites, but have not grown at rates equal to the pre-mining SI. The Birch River (BR-B) mine has higher growth rates than Catenary $(\mathrm{C}-\mathrm{B})$. The mulch treatment at Birch River (BR-M) slightly increased the overall height of northern red oak. The height of red oak at 8 years at both the BR-B and BR-M sites is close to the height of trees growing on the two clear-cut sites (CC-62 and CC75). At age 8 , the height of northern red oak on the Birch River (BR-B) mine $(226 \mathrm{~cm})$ is not the 
same as that predicted by the pre-mining SI $(\mathrm{PBR})$ height $(445 \mathrm{~cm})$. At Catenary $(\mathrm{C}-\mathrm{B})$, the average height of northern red oak at age $10(231 \mathrm{~cm})$ is less than half that predicted by pre-mining SI (PC) height $(570 \mathrm{~cm})$.

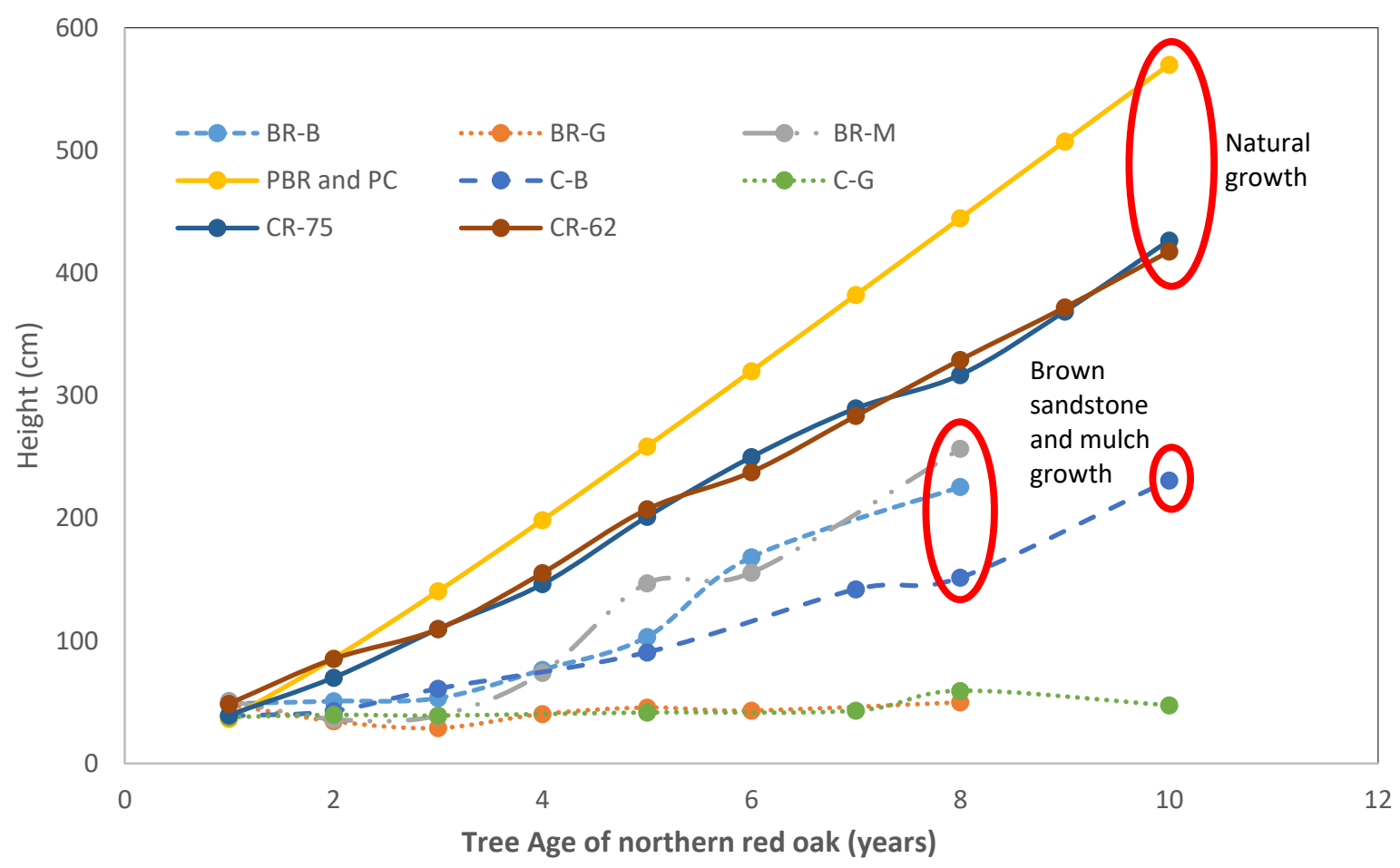

Figure 1. The height of northern red oak growing on two mine sites with different soil types, on two different clear-cut sites, and on estimated pre-mining site.

Figure 2 shows the height of white oak at the two reclaimed sites and the predicted heights from the pre-mining SI. As with northern red oak, white oak growing on gray sandstone (BR-G and $\mathrm{C}-\mathrm{G})$ were not very tall. The white oak on brown sandstone (BR-B and C-B) were taller and growing at faster rates than on gray, with the trees at Birch River growing faster than trees at Catenary. The mulch treatment (BR-M) at Birch River increased the height growth of white oak. White oak on mulch treatments (BR-M) was approximately $130 \mathrm{~cm}$ shorter (approximately 67\%) than the predicted height for the pre-mining SI (PBR). The pre-mining SI at Catenary (PC) was higher than that at Birch River (PBR). The height difference of white oak between Catenary brown sandstone $(\mathrm{C}-\mathrm{B})$ was much lower by $242 \mathrm{~cm}$ than the predicted SI $(\mathrm{PC})$ heights $(641 \mathrm{~cm})$ at age 10. 
JASMR, 2015 Volume 4, Issue 2

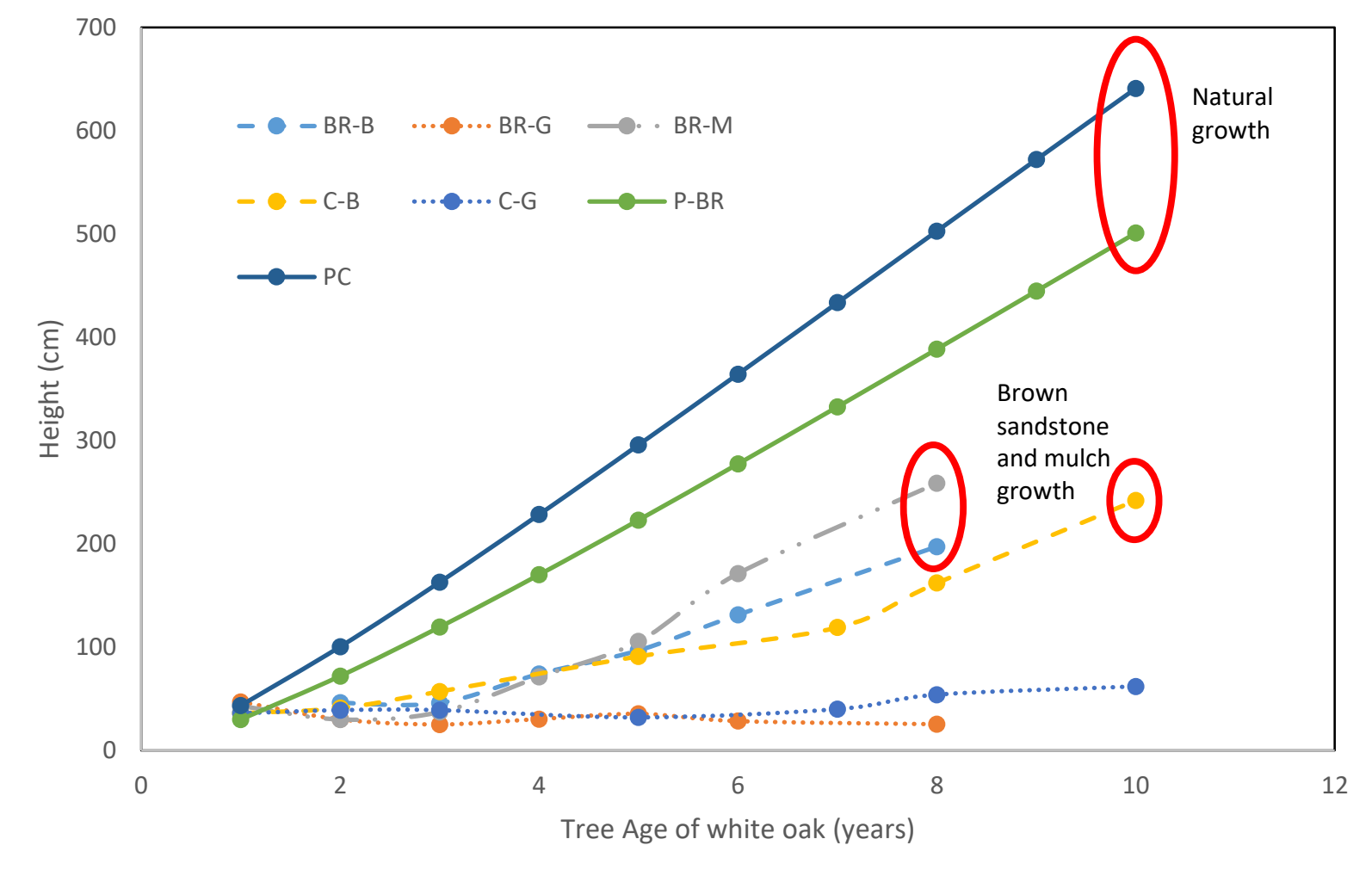

Figure 2. The height of white oak growing on two mine sites with different soil types, and on estimated pre-mining site conditions.

Figure 3 compares the height of tulip poplar growing on the reclaimed mines and clear-cut sites, as well as that predicted by pre-mining SI. Once again, height growth on gray sandstone (BR-G and C-G) was lowest. All tulip poplar heights were higher on the brown sandstone, but height growth at Catenary (C-B) was much lower than at Birch River (BR-B). The mulch treatment (BR-M) had the tallest trees at age 8 of all reclaimed mine sites. Tulip poplar height on the mulch treatment was even higher $(494 \mathrm{~cm})$ than tulip poplar on the SI clear-cut site $(351 \mathrm{~cm}$ on CR-62). At age 10, the height of tulip poplar at Catenary (544 cm on C-B) was higher than on the clear-cut site with the lower SI (503 cm on CR-62). Tulip poplar heights on all mine site treatments were much lower than the pre-mining predicted SI (PBR and PC) heights at all ages.

The tree species discussed in this paper were not growing as fast or as tall as trees in the estimated undisturbed soil conditions (based on the Web Soil Survey). It should be noted that the SI equation used to predict the expected growth of the trees up to 12 years is generally used for older trees. Most site index equations are less accurate when predicting height of younger trees (Carmean et al., 1989). Growth rates on poorer sites, such as reclaimed mine sites, will generally 
increase more slowly than higher quality sites but will maintain this growth for longer time periods (Beck and Trousdell, 1973). Assuming that the reclaimed sites are lower quality sites than the site conditions in the pre-mining forest, it would make sense that the growth is initially slow and may eventually reach the same rates as trees growing on the original site. Initial growth of trees can also be affected by factors other than site quality, such as competition from weeds, animal and insect damage, or differences in stock quality and planting techniques (Carmean, 1975).

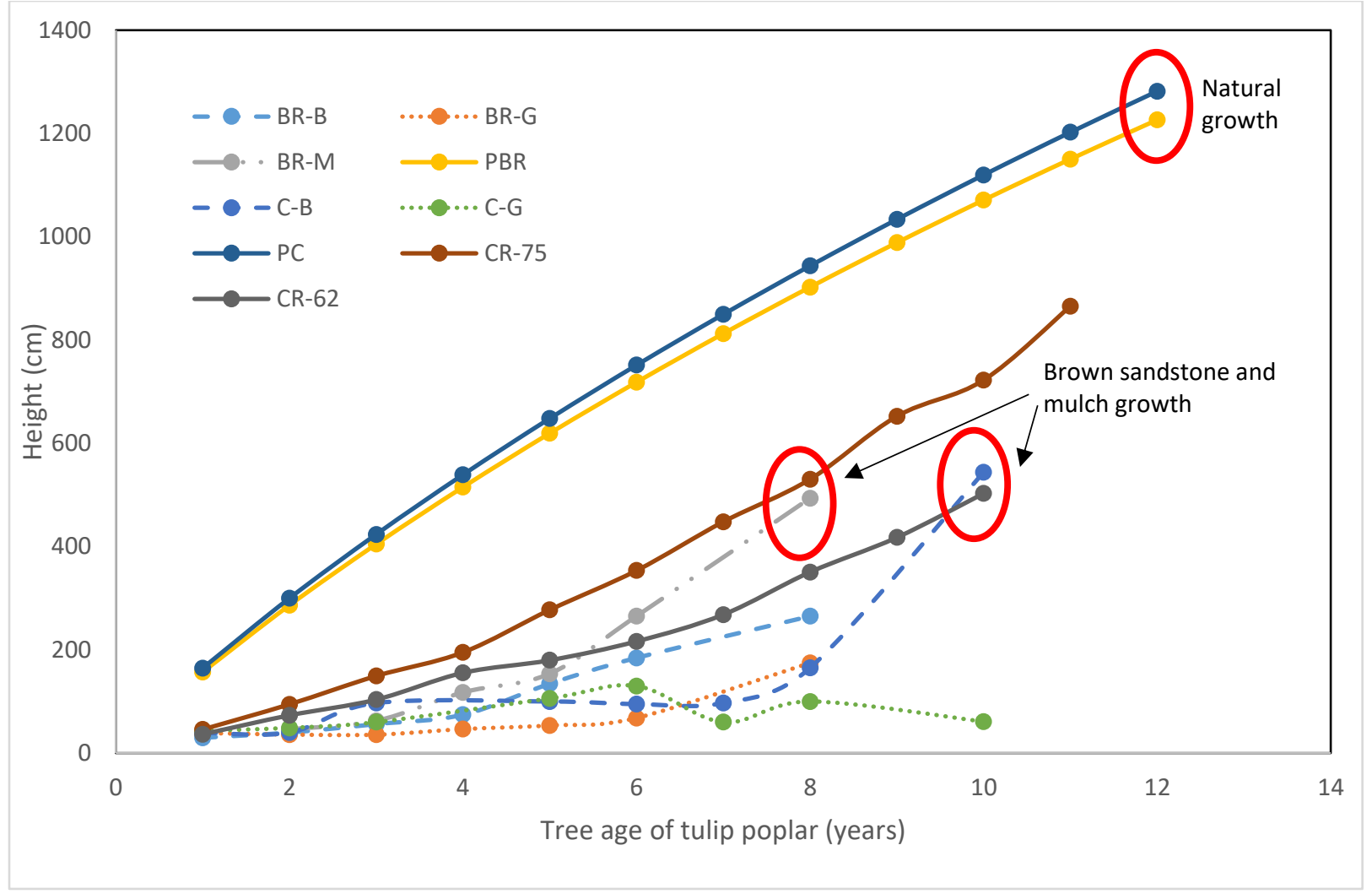

Figure 3. The height of tulip poplar growing on two mine sites with different soil types, on three different clear-cut sites, and on estimated pre-mining site conditions.

The height of trees predicted by SI used in the paper was used to show that reclamation methods are producing trees, but the results show that the reclamation methods used at these sites have yet to produce growth rates similar to the original productivity of the site. Cotton et al. (2012) compared the growth of tulip poplar and white oak on a reclaimed coal mine in Kentucky to the growth of trees in reference forests and found that growth was less than half on mine sites reclaimed with conventional techniques. This study also emphasized that soil amendments on mine soils greatly improved the growth of trees. Other studies have also shown soil amendments on mine soils to improve the growth of trees (Angel et al., 2006; Conrad et al., 2008; Thomas and 
Skousen, 2011; Wilson-Kokes et al., 2013a). A study by Burger and Fannon (2009) found that the SI for tulip poplar was much lower on reclaimed sites (56) than the weighted average pre-mine SI (82). Another study by Groninger et al. (2006) also found site productivity on reclaimed surface mines in Indiana was much below that of native forests in the same region.

\section{Conclusions}

Tree height on Catenary brown sandstone was lower than that on Birch River brown sandstone. The reason for this is unclear as there were no differences between any of the measured soil properties. For all three species, tree heights on gray sandstone $(25$ to $175 \mathrm{~cm}$ ) were lower than tree height on brown sandstone (197 to $544 \mathrm{~cm}$ ). Mulch treatment increased the growth up to 229 $\mathrm{cm}$ on both brown and gray mine soils. The 10-yr-old tulip poplar height on the brown treatment $(544 \mathrm{~cm})$ was greater than heights on the lower quality clear-cut area with a site index 62 (503 $\mathrm{cm})$. Tree heights were lower on mined sites compared to heights on clear-cut sites and those calculated from pre-mining site indices, but mulching improved height growth of trees on mined sites.

\section{Acknowledgements}

We thank Scott Eggerud (US OSM) and John McHale, Mitch Kalos, Jonathan Sanchez, and Jeff Andrews (all of Patriot Coal) for financial and construction support of the Catenary mine project. Thanks are also extended to Keith O'Dell, Bill Young, and Mike Duvall (all of Arch Coal) for funding and support on the Birch River project. The Catenary and Birch River projects are continuation of the work and research of Paul Emerson, Curtis DeLong, Calene Thomas, and Lindsey Wilson-Kokes. We thank them for all the hard work they've completed since the beginning of each project. Finally, we would like to thank Steffany Scagline, as well as many other WVU graduate students, who have helped in the collection of data for each project.

\section{$\underline{\text { Literature Cited }}$}

Angel, P., C. Barton, R. Warner, C. Agouridis, T. Taylor, and S. Hall. 2008. Forest establishment and water quality characteristics as influenced by spoil type on a loose-graded surface mine in eastern Kentucky. Proceedings America Society of Mining and Reclamation, 2008 pp 28-65. http://dx.doi.org/10.21000/JASMR08010028 
Angel, P., V. Davis, J. Burger, D. Graves, and C. Zipper. 2005. The Appalachian regional reforestation initiative. Forest Reclamation Advisory No. 1. p. 1-2. Available at http://arri.osmre.gov/Publications/Publications.shtm\#FRAs. Accessed 8 January 2015.

Angel, P.N., D.H. Graves, C. Barton, R.C. Warner, P.W. Conrad, R.J. Sweigard, and C. Agouridis. 2006. Surface mine reforestation research: evaluation of tree response to low compaction reclamation techniques. 7th International Conference on Acid Rock Drainage, 2006 pp 45-58. http://dx.doi.org/10.21000/jasmr06020045.

Beck, D.E. and K.B. Trousdell. 1973. Site index: accuracy of prediction. USDA Forest Service, Southeastern Forest Research Station. Research Paper SE-58. Asheville, NC.

Bigelow, S.W., and C.D. Canham. 2007. Nutrient limitation of juvenile trees in a northern hardwood forest: calcium and nitrates are preeminent. Forest Ecology and Management. 243:310-319. http://dx.doi.org/10.1016/j.foreco.2007.03.027.

Bise, J.B. 2013. Coal industry statistics. p. 1-23. In C.J. Bise (Ed.) Modern American coal mining methods and applications. Society for Mining, Metallurgy, and Exploration, Inc. Englewood, CO.

Bowling, K.C. 1978. History of legislation for different states. p. 95-116. In F.W. Schaller and P. Sutton (Eds). Reclamation of drastically disturbed lands. American Society of Agronomy. Madison, WI.

Burger, J.A. 1999. Academic research perspective on experiences, trends, constraints and needs related to reforestation of mined lands. p. 63-74. In: Proceedings, Enhancements of Reforestation at Surface Coal Mines: Technical Interactive Forum, March 23-24, 1999. Fort Mitchell, KY.

Burger, J.A. and A.G. Fannon. 2009. Capability of reclaimed mined land for supporting reforestation with seven Appalachian hardwood species. Proceedings America Society of Mining and Reclamation, 2009 pp 176-191. http://dx.doi.org/10.21000/JASMR09010176.

Burger, J., D. Graves, P. Angel, V. Davis, and C. Zipper. 2005. The forestry reclamation approach. Forest Reclamation Advisory No. 2. p. 4. Available at http://arri.osmre.gov/Publications/Publications.shtm\#FRAs. Accessed 8 January 2015. 
Carmean, W.H. 1975. Forest quality evaluation in the United Sates. Advances in Agronomy. 27: 209-269. http://dx.doi.org/10.1016/S0065-2113(08)70011-7.

Carmean, W.H. 1977. Site classification for northern forest species. p. 205-239. In: Intensive Culture of Northern Forest Types Symposium Proceedings. USDA Forest Service General Technical Report NE-29.

Carmean, W.H., J.T. Hahn, and R.D. Jacobs. 1989. Site index curves for forest species in the eastern United States. USDA Forest Service, North Central Forest Experiment Station. Gen. Tech. Rep. NC-128. St. Paul, MN.

Conrad, P.W., R.J. Sweigard, V. Badaker, D.H. Graves, and C.D. Barton. 2008. The impact of surface applied mulches on selected physical properties of reclaimed mountaintop removal sits. Inter. J. Mining, Reclamation and Environment. 22:222-236. http://dx.doi.org/10.1080/17480930801961948

Cotton, C., C. Barton, J. Lhotka, P.N. Angel, and D. Graves. 2012. Evaluating reforestation success on a surface mine in eastern Kentucky. USDA Forest Service Proceedings. RMRS-P-68.

Daniels, W.L. and D.F. Amos. 1985. Generating productive topsoil substitutes from hard rock overburden in the southern Appalachians. Env. Geochem. \& Health. 7:8-15. http://dx.doi.org/10.1007/BF01875045

Emerson, P., J. Skousen, P. Ziemkiewicz. 2009. Survival and growth of hardwoods in brown versus gray sandstone on a surface mine in West Virginia. J. Environ. Qual. 38:1821-1829. http://dx.doi.org/10.2134/jeq2008.0479

Groninger, J.W., S.D. Fillmore, and R.A. Rathforn. 2006. Stand characteristics and productivity potential of Indiana surface mines reclaimed under SMCRA. N.J. Appl. For. 23:94-99.

Haering, K.C., W.L. Daniels, and J.M. Galbraith. 2004. Appalachian mine soil morphology and properties: effects of weathering and mining method. Soil Sci. Soc. Am. J. 68:1315-1325. http://dx.doi.org/10.2136/sssaj2004.1315.

NCSS. 2015. National Cooperative Soil Survey Characterization Database. Accessed online at: http://ncsslabdatamart.sc.egov.usda.gov/. Accessed on: 30 June 2015. 
Plass, W.T. 2000. History of surface mining reclamation and associated legislation. p. 1-20. In R.I. Barnhisel et al. (Eds) Reclamation of drastically disturbed lands. American Society of Agronomy. Madison, WI.

Rodrigue, J.A. and J.A. Burger. 2004. Forest Soil productivity of mined land in the Midwestern and Eastern coalfield regions. Soil Sci. Soc. Am. J. 68:833-844. http://dx.doi.org/10.2136/sssaj2004.8330.

Sena, K., C. Barton, S. Hall, P. Angel, C. Agouridis. 2014. Influence of spoil type on afforestation success and natural vegetation recolonization on a surface coal mine in Appalachia, United States. Restoration Ecology. Available at http://onlinelibrary.wiley.com/doi/10.1111/rec.12164/pdf. Accessed 08 February 2015.

Showalter, J.M., J.A. Burger, and C.E. Zipper. 2010. Hardwood seedling growth on different mine spoil types with and without amendment. J. Environ. Qual. 39: 483-491. http://dx.doi.org/10.2134/jeq2008.0500

Skousen, J. and C.E. Zipper. 2014. Post-mining policies and practices in the Eastern USA coal region. Int. J. Coal Sci. Technol. 1 (2): 135-151. http://dx.doi.org/10.1007/s40789-014-00216 http://arri.osmre.gov/FRA/Advisories/FRA_No.8\%20Soil\%20Materials.pdf. Accessed 08 February 2015.

Skousen, J. and C.E. Zipper. 2013. Reclamation of surface mines. p. 407-476. In C.J. Bise (ed.) Modern American coal mining methods and applications. Society for Mining, Metallurgy, and Exploration, Inc. Englewood, CO.

Skousen, J. and C.E. Zipper. 2014. Post-mining policies and practices in the Eastern USA coal region. Int. J. Coal Sci. Technol. 1 (2): 135-151. https://doi.org/10.1007/s40789-014-0021-6

Smith, H.C. 1983. Growth of Appalachian hardwoods kept free to grow from 2 to 12 years after clearcutting. USDA Forest Service, Northeastern Forest Experiment Station. Res. Paper. NE528. Broomall, PA.

Thomas, C. and J. Skousen. 2011. Hardwood tree performance on amended brown and gray mine spoils after four years. Proceedings America Society of Mining and Reclamation, 2011 pp 665675. http://dx.doi.org/10.21000/jasmr11010655. 
JASMR, 2015 Volume 4, Issue 2

Trimble, G.R. 1973. Response to crop-tree release by 7-year old stems of yellow-poplar and black cherry. USDA Forest Service, Northeastern Forest Experiment Station. Res. Paper. NE-253. Upper Darby, PA.

USDA. 2014a. Fernow Experimental Forest. Available at http://www.nrs.fs.fed.us/ef/locations/wv/fernow/local-resources/docs/nrs_inf_14_12fernow.pdf. Accessed 13 February 2015.

USDA. 2014b. Web Soil Survey. Available online at http://websoilsurvey.sc.egov.usda.gov/App/WebSoilSurvey.aspx. Accessed 01 February 2015.

U.S. Energy Information Administration (EIA). 2013. Annual coal report 2012. Available at http://www.eia.gov/coal/annual/pdf/acr.pdf. Accessed 19 January 2015.

Wilson-Kokes, L., C. Delong, C. Thomas, P. Emerson, K. O'Dell, and J. Skousen. 2013a. Hardwood tree growth on amended mine soils in West Virginia. J. Environ. Qual. 42:13631371. http://dx.doi.org/10.2134/jeq2013.03.0103 http://dx.doi.org/10.2134/jeq2013.04.0113

Wilson-Kokes, L., P. Emerson, C. Delong, C. Thomas, and J. Skousen. 2013b. Hardwood tree growth after eight years on brown and gray mine soils in West Virginia. J. Environ. Qual. 43:1353-1362. http://dx.doi.org/10.2134/jeq2013.04.0113 PMid:24216413.

Zipper, C.E., J.A. Burger, J.G. Skousen, P.N. Angel, C.D. Barton, V. Davis, and J.A. Franklin. 2011. Restoring forests and associated ecosystem services on Appalachian coal surface mines. Environmental Management. 47:751-765. http://dx.doi.org/10.1007/s00267-011-9670-z 